大きさを選び，脈動流の平均フロート位置誤差が減じ られる。 [千葉近]

\subsection{3}

[115]直接数字成形式ディジタルプリンタ [D. Janess, Instruments \& Control Systems, 1965-4, Vol. 38 , No. 4, p. 127 129, 図 6] ディジル電生計 や計数器の出力を記録するためのプリンタで，機械的 構造を簢単化することにより記録速度を向上させたも のである、バートトラムなどを使わずに数字を直接七 つの切片の組合せで形づくりそれをタイプライタのリ ボンをとおして記録紙に印字する。へッドには数字形 成用の七つの切片と区点用の一切片が付属していてお のおの制動レバーで所要の位置にロックされる.

制動レバーにはばねがついていて，電磁石への入力 により止め金がはずれることによって作野し，印学用 切片を印字位置に固定する。不要の切片は浮動状態に おかれるが質量が小さいため愦動作のおそれはない。 プリンタの入力は 8-4-2-1 BCD 形で, .トランシスタ 論理回路により各切片駆動用の 2 進命令信号に変換さ れ電磁コイルに送られる。ヘッドと対向してコムロー ラが配置されていて，ローラ内面の歯形とかみあった 偏心霜車を同軸の偏心クランクにより駆動することに より回転し記録紙を送る。プリント速度は $10 \mathrm{line} / \mathrm{s}$ でバーおよびホイール形の 2〜5 倍である。

[山本笽]

681.846.7: 538.24 .087

[116] 磁気記録装置 [M.H. Aronson, Instruments \& Control Systems, 1965-7, Vol. 38, No. 7, p. 88 98，因 19，表 3] 磁気テープの記録・再生過程の 原理を簡単に述へ，従来使用されてきた記録方式を説 明した上，新しい磁気記録方式および装惪を紹介して いる.プレデテクション記録方式による広芇域磁気 記録装置はテレメータリング・データの取得・処理装 置を標準化するのに役立っている。これはへテロダイ ン検波した中間周波信号を誼接磁気テープ上に記録す るもので, PAM-FM, PACM-FM 方式の信号記録に 特に適しており，振幅の安定度は $0.5 \%$ 以内，周波数特

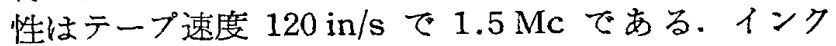
レメンタル・テープ駆動装置は入力の周期が広範囲に 変わっても，いちような密度で磁気テープ上に記録す る装置で，不規則信号を記録するときに有利であり， この出力は值接電子計算機に接続できる．超小形記録

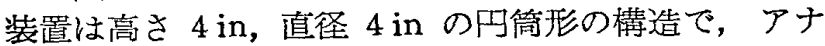
ログおよびディジタル記録のできるむのなど数種が宇 宙開発用のデー夕記録に用いられている。このほか 2 台の記録・再生装置を遅延箱（テープ長さ 36 in 125 ft）をはさんで 1 台のテープ駆動部と組合せた装置や 過渡的データの解析，データの一時的貯蔵に使用され るループ式駆動装置が述へられている。【杉山

\subsection{2 .5}

[117]光てとと投影拡大法の比較 [H. Ulbricht, Feinwerktechnik, 1965-2, Jg. 69, Ht. 2, S. 56 64, 図 21, 表 2] 光学的搪大法を 2 大勋しで光てこに よる法と，目盛板を動かしてこれをスクリーン上に拡 大して読む投影法とを比較解説している．光てこの動 く部分は鏡であるから慣性を十分小さくできるが，投 影法は目盛板を動かすのであるから鏡に比べれば慣性
が大きく，したがって後者は静的な䝭定やゆっくり变 化する量の测定にしか用いられない。感度も一般には 光てこのほうが大きく，光学系もこのほうが簡単にな るなど長所が多いが，投影法は読みやすいという点で すぐれている。また測定範围も投影法の汪うが大きく とれる。

光てこ法で固定鏡を使って 2 回以上光が可動鏡に当 たるようにすると感度はさらに増すが，鏡を大きくし ないと光路が鏡からはずれてしまうから測定範囲がき わめて小さくなり零点法のような目的にのみ用いられ る。互いに少し角度をなす鏡を組合せ一方の鏡を反射 した光がスケールアウトするとつぎの鏡の光が目盛に はいってくるようにして測定範用を增すくふうもあ る. 投影法で目盛を哩加す代わりに途中の光学系にあ る鏡を動かすようにすれば慣性の点では改善される。

[神保泰雄]

\section{$535.215: 621.383$}

[118] 光電変換素子 [J.R. Mcdermott, Contr. Engng., 1964-10, Vol. 11, No. 10, p. 71 84, 図 37, 表 2]固体素子の䦎発が制䘖工学に光電变換技術を 利用する好機となった。可視または近赤外の波長域で 使用される素子が重要であり，これらを標準化するに はまだ時間を要する。これら素子を正しく選択するた めの素子の評価, 特性および影響する要因が述へらられ ている. 光導電効果, 光起電効果, 光電子放射効果の 三つが実用されており，前二者の固体セルを今日では 括もに用いているが，光電子放射効果は最初に笑用化 されたものであり，特に高周波特性，滈感度を要求す るときに重要である，光導電セルは光の照射により導 電率功增加するもので，合金形と接合班とある。合金 形には CdS, CdSe, PbS, 接合形にはホト・ダイオー ト, ホト・トランジスタ, ホト電界勃果トランシス 夕，PNPN スイッチ・トランジスタがある. 光起電セ ルは光の照射により起電力を生ずるもので, Se, Si がある. 光電感度, 暗電流, 周波数特性, 電流容量な ぞの性能および周盟温度, 䀠加電王, 負荷抵抗, 光量 などの影響を詳細に述べている。 [杉山 博]

\subsubsection{7}

[119]ディジタル温度計 [T. Coor \& L. Szmauz, Instruments \& Control Systems, 1965-5, Vol. 38, No. 5, p. $125 \sim 127$, 図 6] 制御用としても使用可能 な白金線抵抗を䄼出プローブとするディシタル表示式 高精度温度訊についてのべている．測定回路はろルビ ンブリッシを変形したものが主体で,ブリッシの複合 2 辺として測定用白金線とそれの温度特性と相似の非 線形関数抵抗およびそれそれに直列に接続された可変 抵抗分連動するような構成をとることにより，プロー ブの導線抵抗值に䦪係なく温度を測定しようとするも のである．関数抵抗は 4 けた 10 進の 2-4-2-1 方式で 水銀リレーが切換えに使用される.ブリッジの不平衡 検出出力により選択スイッチを駆動させ士200,400, $200 \cdots \cdots 1,0.2,0.4,0.2,0.1^{\circ} \mathrm{C}$ に相当する抵抗の組 合せを試み，平衡点における值を表示管により指示す る.制御用として使用する場合は所要の設定値をディ ジル選択スイッキでセットしておきこれに相当す る抵抗値とプローブで测定される温度に相当する白金 線の抵坑值との差によって生じたブリッシの不平衡出 